\title{
Changes of the Tibet Ritual: A Case Study of Tibet Religion Ritual's Changes
}

\author{
Diyu Xie ${ }^{1, *}, \dagger$, Yimao Zhao ${ }^{2, \dagger}$ \\ ${ }^{1}$ Drew University, New Jersey, US \\ ${ }^{2}$ Zhengzhou Foreign Language School, He Pei Province, China \\ ${ }^{*}$ Corresponding author. Email: Dxie@drew.edu \\ ${ }^{\dagger}$ These authors contributed equally.
}

\begin{abstract}
This study focuses on the changes in religion-based customs in Tibetan history. The reason of these ritual changes is divided into two paths. . The first one deals with the historical understanding of customs in Tibet which can be roughly divided into two periods, one is the period of integration of politics and religion in early Tibet, and the other is the period of separation of politics and religion from 1959 to the present. The second path will introduce other factors that have influenced the change of Tibetan customs in various periods, such as the development of government structure, religious structure, and serfdom. Through the study of the "hail proof" ceremony and "laze" ceremony, this paper analyzes the changes of these ceremonies and their causes.
\end{abstract}

Keywords: Tibet religion, Tibet’s modern history, China politics.

\section{INTRODUCTION: THE HISTORY OF TIBET AND ITS RELIGION}

From the middle of the 9th century to the middle of the 13 th century, it was more than 400 years from the end of the Tubo dynasty to the Sakya regime. This period was a period of transition from slavery to feudal serfdom in Tibetan society. However, during this period, Tibet was dominated by various large and small regimes, which made the vast Tibetan region without a unified regime and leadership. This period is generally referred to as the "Separated Tibet Period" [1]. During this period, Buddhism also spread to Tibet from India and the Central Plains. Tibetan historical records divide the development of Buddhism in Tibet into two historical stages, among which the period of the Tubo Dynasty from the middle of the 7 th century to the middle of the 9th century is the "pre-prosperity period" [2]. By then, Buddhism was still a foreign religion in the Tubo dynasty, and it developed in the constant struggle with the original "Bon religion" in the local area. During this period, it once occupied an advantage. Some scholars believe that the Buddhism movement throughout the entire Tubo dynasty The phenomenon of Buddhist monks interfering in politics once appeared in China, and the integration of politics and religion in the "post-proliferation period" of Tibetan Buddhism originated here. The existence of separatist forces and the formation and development of Tibetan Buddhism are the two major characteristics of this period.

These two are also very related. The reason why Buddhism can be revived in Tibet in the "postproliferation period" is the result of the direct promotion of local separatist forces. With the emergence and development of some Buddhist sects, the relationship between Buddhist powers and local separatist forces has become closer. Even in some places, the two are combined into one, which is the "integration system of church and state" $[2,3]$. During the development of Buddhism in the "post-proliferation period," it not only absorbed the things of Bon religion but also absorbed a lot of content from late Indian Buddhism. Therefore, Tibetan Buddhism has a unique local color.

The reason why the Sakya integration of state and religion can leap from many sectarian forces and integration of state and religion to become the hegemon of Tibet is mainly dependent on the support of the Mongolian government. It was with the full support of the Mongol rulers that the Sa Ying regime was able to be established, which led to the establishment of the unity of politics and religion in Sa and Ying. As a local government of the Yuan dynasty, the Saying regime is completely under the direct jurisdiction of the central government of the Yuan dynasty; similarly, the operation 
of the Sakya political-religious unity system is also under the central government of the Yuan dynasty. The emperor is a very good symbol under full manipulation and control. As the leader of Tibet's integration of politics and religion, he is also the leader of Buddhist monks across the country and the emperor's religious teacher, and his status is extremely respected. According to the "Yuan History", the Yuan court said to the emperor, during a hundred years, the imperial court respected and respected those who did everything. Although the emperors and concubines were worshipped for taking the ordination. The prosperity of the emperor's teacher, especially not the same as the ancient past" [4].

In 1354, the Pamudrukpa Kagyu Sect, headed by the Lang family, began to take charge of the power of local politics and religion in Tibet, and it was granted by the central government of the Ming Dynasty. After the establishment of the Pamudruba regime, a series of regulations were promulgated such as the "Fifteen Articles of the Code," and the establishment of a patriarchal system, which further strengthened the Tibetan-state-religious unity system. In 1642, the Gelugpa seized the political and religious power in Tibet and established the Gadan Podhang regime in Drepung Monastery. In 1653, the fifth Dalai Lama was canonized by the Qing government. Since then, the Qianlong Dynasty of the Qing Dynasty successively issued the "Thirteen Articles of Regulations for Rehabilitation of Tibet" and "Twenty-Nine Articles of Regulations for Rehabilitation in Tibet". Not only realized the Qing government's institutionalization and standardization of Tibet's governance, but it also formally confirmed the status of religious leaders in the Gelugpa Dalai system and the Panchen Lama system of Tibetan Buddhism, making them equal status with the minister in Tibet. The right to govern Tibet. This period became the complete period of Tibet's integration of politics and religion. One of the main characteristics of the social and political system of old Tibet was that the Dalai Lama, as the main leader of the Gelug Sect of Tibetan Buddhism, also served as the head of the Tibetan local government, integrating politics and religion. The Dalai Lama himself is not only the general representative of this unity of church and state system but also the largest serf owner. At the same time, the serf-owning class, composed of three lords of officials, nobles, and upper-class monks in monasteries, carried out extremely cruel political oppression and economic exploitation of serfs and slaves. The state of shrinking. Religious power has expanded under the old Tibet's integration of politics and religion, which consumes a large number of human resources and most of Tibet's material wealth, confines people's thinking, and becomes a heavy shackle that hinders the development of productive forces. Since the beginning of 1949, with the successive victories of the Chinese People's Liberation War, the Central Committee of the Communist Party of China has gradually made clear and specific considerations and plans for resolving the Tibet issue and has placed an important work schedule on it. In February 1949, Mao Zedong discussed the liberation of Tibet with visiting member of the Political Bureau of the Communist Party of the Soviet Union Mikoyan. He pointed out that the Tibet issue is not difficult to resolve. On the eve of the establishment of New China, to expel the imperialist aggressive forces and complete the unification of the motherland's territory and sovereignty, the Central Committee of the Communist Party of China made a strategic decision to liberate Tibet and ordered the People's Liberation Army to march into Tibet and build Tibet [5]. In August 1949, the Central Committee of the Communist Party of China and Mao Zedong instructed the Northwest Bureau of the Central Committee of the Communist Party of China and the First Field Army to prepare for the settlement of the Tibet issue when marching into the northwest. Subsequently, according to the actual situation, the strategic task of marching into Tibet was mainly assigned to the Chinese army. On September 26, Commander-in-Chief Zhu De made three solemn pledges at the Chinese People's Political Consultative Conference. The first of these was to ensure the liberation of all territories, including Tibet and Taiwan, and complete the great cause of the reunification of the motherland. In October 1950, the People's Liberation Army marching into Tibet liberated Qamdo, smashing the conspiracy of imperialists and local separatist forces in Tibet to prevent the People's Liberation Army from marching into Tibet and opening the door to Tibet. While deciding to march into Tibet, the Central Committee of the Communist Party of China took a series of measures to try to negotiate with the local government of Tibet to peacefully liberate Tibet. This is because if Tibet can achieve peaceful liberation, it will be very beneficial to the reunification of the motherland, the strengthening of ethnic unity, and the maintenance of social stability in Tibet. To this end, the Central Committee of the Communist Party of China, the Southwest Bureau, and the Northwest Bureau are all vigorously fighting for it. In April 1951, the Tibetan local government sent a delegation to Beijing. After a month of negotiations, on May 23, the "Agreement between the Central People's Government and the Tibetan Local Government on Measures for the Peaceful Liberation of Tibet" (referred to as the "17-Article Agreement") was signed, proclaiming the peaceful liberation of Tibet. Peaceful liberation achieved equality and unity between the Tibetans and all ethnic groups in the country and laid the foundation for Tibet to implement democratic reforms and regional ethnic autonomy. On May 28, the "People's Daily" published the full text of the agreement in both Tibetan and Chinese, and reported the progress of the peace negotiations. Once the "17-Article Agreement" was promulgated, the Panchen Lama and all the staff of the Panchen Khenpo Conference Hall issued a statement supporting the agreement on the peaceful liberation of Tibet. On June 1, the Panchen Lama called Chairman 
Mao to express his sincere support for the agreement and to work hard for the realization of the agreement and for the Tibetan nation to be free from imperialist fetters, liberate and develop forever. On October 24, the Dalai Lama called Chairman Mao to support the agreement on the peaceful liberation of Tibet [5].

However, the Tibetan local government and upperlevel reactionary groups, under the instigation and support of imperialism and foreign reactionary forces that are hostile to China, resorted to arrogant means. They expressed their support for the central government's decision while facing the central government's falsehood and coping. Moreover, they secretly colluded with foreign anti-China forces, stepped up planning activities to split the motherland, provoked local armed rebellions in various parts of Tibet from time to time, and strengthened their internal governance and control. Strive to consolidate its sinful serfdom system. Around 1958, local rebellions in Tibet had gradually escalated, which seriously threatened the production, livelihood, and lives of the people of all ethnic groups in Tibet and the staff of party and government agencies.

\section{A CLOSE LOOK: THE SECOND STAGE}

During the period 1952-1959, the Chinese government preferred to prove to the world that Tibet was a part of China. The first Chinese troops entered Tibet, while Deng Xiaoping told them in Chengdu not to mention class struggle and communism when they arrived in Tibet, but focus your work only on helping the poor [6]. When the Chinese government first entered Tibet, they simply built basic facilities and denied the right to hold private courts to promote friendship with the Tibetans. China faced a paradox in that it did not want to interfere excessively to cause dissatisfaction in Tibet and wanted to reduce the pressure on the farmers to win support which displeased the ruling class at the time [6]. Later in 1959, an armed coup took place in Tibet and the Chinese PLA quickly settled the battle. After that, China decided to dissolve the local government and start a democratic revolution. Tibet has since separated church and government and abolished serfdom and put many monks to work in farming. As events unfolded, despite the erroneous Han chauvinism mentioned by Deng Xiaoping, many people volunteered to go to Tibet to start the revolution during the Great Cultural Revolution, as Tibet was much slower to reform than other provinces. This led to a ten-year absence of religion in Tibet. Later the Chinese government realized its mistake and repromoted freedom of religion.

\section{LAZE CEREMONY}

"Laze" sacrificial rituals can be seen everywhere in the entire Tibetan settlements. It is not only one of the main manifestations of Tibetan mountain god worship, but also an ancient belief practice that integrates nature worship, ancestor worship, and reproductive worship. Tibetans have lived on the Qinghai-Tibet Plateau for generations. In Tibet, any mountain is considered to have a god on it. These gods can not only benefit society but also be evil among people, thus forming a "reciprocal" relationship between people and gods. Therefore, people should regularly hold sacrificial rituals to maintain the normal relationship between man and god. Among all the rituals for offering sacrifices to mountain gods, "Laze" sacrifice is the most important way. The ritual of planting an arrow to respect the mountain can make the teaching method prosper, the kings and the ministers will live a long and healthy life, the people's descendants will be full, the wealth will be prosperous, and the disease will be cured and longevity. In addition, every time new temples, pagodas, homes, farming, expeditions, worship of "Dorma" rituals, newlyweds, anti-thunder and hail, and learning about Buddhism, etc., there will be arrowinsertion activities. From the perspective of cultural genetics, the formation of any kind of cultural phenomenon has its social roots and historical background and generally has to go through stages of germination, growth, and development. The Tibetan "Laze" sacrificial rituals also went through such processes [7]. To cherish the memory of the tribal leaders and the elders of the blood relatives for the achievements made to the tribe, and to pray for the souls of the ancestors to continue to bless the clan and the tribe, the people enshrine the bows, arrows, spears, swords and other weapons used by the ancestors. Where they depend, pray for their protection, and at the same time encourage their children and grandchildren to move forward courageously. Among the many weapons, the "arrow" is one of the typical features of the ancient Tibetan nomadic culture.

The Tibetan "Laze" arrow-inserting sacrifice consists of two parts: underground and above ground. The underground part is mainly for burying some treasures, including a wooden stake erected in the center of the dug pit, called the "life tree", on which white wool is tied. rope. Place aquariums, weapons, etc., containing food, gold, and silver, jewelry, etc., around the "wood of life". There are stones on the ground, and cypress, birch, bamboo, and wooden swords and arrows, white wool, khata, jingpan, etc. are inserted on the ground.

Regarding the function of "Laze", there are two theories as follows: Firstly, it symbolizes the status of the family. The famous Tibetan scholar Gengdeng Qunpei believes that "Laze" began in the Zanpu era. When Songtsen Gampo built his palace in Hongshan, he inserted arrows on the roof as decoration, and later became a symbol of Zanpu's authority and a religious custom. Secondly, Laze is understood as a signpost. Some scholars believe that Tibetan ancestors lived on vast plateaus for generations and were sparsely populated. In order not to lose their way or distinguish the 
boundaries when they went out nomadic, they established "Laze" on important mountain tops and gaps; some scholars also believe that predatory wars between Tibetan tribes in primitive society Frequently, to prevent the troops from expeditions from getting lost on their way back, "Laze" was set up. Later, it gradually evolved into a ritual to worship the spirits. By offering sacrifices to the warriors who died on the battlefield, the souls of the warriors could protect their tribe's people from defeating. opponent. Judging from the fact that "Laze" has a large number of weapons such as feather arrows, swords, and so on, and some "Laze" also represents a certain war god, it is indeed related to the military activities of ancient tribes. The "Laze" sacrifice is a concentrated expression of the worship of the Bon god of war. And, in the 7th century, due to the introduction of Buddhism, the meaning and functions of Laze changed after the Bon religion fought against Buddhism. Through these analyses, we believe that the changes in these rituals are not simply due to one reason. People have to start from many angles. For example, the "Laze" ceremony was originally influenced by the Tibetan religion "Bon". Later, due to the introduction of Buddhism, "Bon" and Buddhism also had a certain conflict in Tibet. With integration, this forms the meaning of the "Raze" ritual. Tibetan tribal wars are extremely frequent. To reduce casualties, relatives and friends must hold grand arrowinserting ceremonies whenever they go out or face raids by other tribes to win victory. In ancient societies where there was almost no science, wars could not do without arrows, heroes could not do without arrows, and victory could not do without arrows. But in modern times, people hold pulls to pray for peace and happy life. These are not only because people live in different times, but also because people's quality of life and technology have been greatly developed.

\section{RITUAL OF HAIL PROOF}

After an introduction to the dramatic changes in Chinese history, certain Tibetan religious rituals have similarly changed. For this case study, it chose the ritual of Hailproof as the sample and its history through two ethnographies and an interview with a living master of hail proof, a ser srung.

According to Grunfeld's assessment of Tibetan social structure, the Tibetan rulers held Buddhist ideology as the highest spiritual support, critical parts of the religious group [1]. The supreme leader of whom was the Dalai Lama, The Dalai Lama was not only the supreme leader of Buddhism in Tibet but also the supreme leader in politics. Next was a regent, who assisted the Dalai Lama in governing Tibet. regent was a person chosen by both the religious nobility and the secular nobility. regent ran all the secular departments. Kashag will report classified information to regents from each department. Tibet tended to tend to have secular nobles and monastic officials administering a single department together. In addition, the Dalai Lama and the Regent jointly administered the religious department of Tibet, and in this one department, it would be all monastic officials.

Serfdom can be considered as the main part of the Tibetan economic system. The old Tibetan society was very similar to the Indian caste system. India determines a person's occupation based on the caste system. The Tibetans were very dependent on the land. Land determined status and land was often hereditary. with noble monks or secular nobles achieving hereditary status by controlling the sources of education and the staff system (school places were few, and serfs had onerous tasks to complete and could not leave). The serfs were considered to have done wrong in their past lives and karma punished them, so they could only obey. Among other things, the responsibility of supporting Tibetan logistics deeply limited the serfs' finances. The serfs were obligated to home breed cattle and horses to help the Tibetan logistics system. So even if there was no logistical task at all, they had to buy enough fodder to maintain the logistical system.

The main religion is Buddhism, and it has been the leading religion in Tibet since the completion of secularism. The mainstream of Tibetan Buddhism is the Gelug school, in addition to the Nyingma School (Red Sect), Sakya School (Flower Sect), Kagyu School (White Sect), Gelug School (Yellow Sect). From the huge number of monks, it may be concluded that gdamasa gsum is not only a Buddhist monastery but also a fully functional "city". The struggle between the interests of the Buddhist forces within Tibet was so fierce that even the grwa tshang, which belonged to the same monastery, fought with each other. This is largely a peculiarity of the living Buddha system. Each Dalai Lama succeeded the Dalai Lama from infancy, and because of the harsh natural and sanitary conditions in Tibet, the ninth Dalai Lama (1805-1815) and the tenth Dalai Lama (18161837), according to history, did not even hold political power. Only the Eighth Dalai Lama (24years) and the Thirteenth Dalai Lama (38years) governed Tibet for a longer period. The rest of the Dalai Lamas did not govern Tibet for more than 10 years. On the one hand, the regent was elected, which would have created a huge battle for power. On the other hand, although the Dalai Lama has the veto power over everything, often the options for many things are provided by the regent or other representatives. For example, when the Dalai Lama is deciding who will hold an official job, although the Dalai Lama has the right to deny, the list is provided by a subordinate so the Dalai Lama is not free to choose. This is a means that even if there is no external power interference in Tibet the local Tibetan religion does not have complete control over political power

The Ritual of Hailproof originated from the Bon religion and was later improved by the Nyingma school 
of Tibetan Buddhism, which learned the knowledge of the Bon ritual of hail proof technique. "Today's hail prevention techniques are almost always based on Buddhist scriptures rather than on the Bon religion. And Tibetan Buddhism created a new profession of hail master (ser srung) specifically to hold hail prevention skills professionally" [8]. Ser srung is second to a lama in Tibet in terms of religious status and is often hereditary. Unlike senior Tibetan monks and nobles, ser srung do not rely greatly on their land ownership but are paid to make ends meet. A ser srung needs two skills, one is the knowledge of weather and the other is the understanding of Buddhist scriptures. Also, the profession of ser srung has been abolished in Tibet since 1959. During the democratic reform in Tibet, Mao Zedong explicitly wanted to reduce the number of Tibetan monks $(110,000$ to a few thousand), and the abolition of ser srung was included in the reduction list [5]. But what made people stop trusting in ser srung and stop holding rites of hail proof was the introduction of technology, and local people stopped trusting in ser srung after they realized that using anti-aircraft guns to prevent hail was very effective.

Regarding the details of the ritual of hail proof, the master, which is known as ser srung tends to live alone and meditate all the time for 14 days before the ritual is held. During the rituals, spells are used and different scriptures are recited depending on the weather. ser srung spells vary depending on the family, most are made of cow horns, and the spells are not allowed to be touched by women [9].

In other words, people no longer perform rituals of hail proof, or in some areas such as Ngari, Lamu, Tingri, Sakya, and Tinggi, they still do, but the locals do not think of it as a religious ritual, but rather as a festival on the eve of crop harvesting, probably in July, called "sgyeda-sgye-mo" or "sgye-da" [10]. According to Sunlin's ethnography, "sgye-da-sgye-mo" is a festival consisting of 24 songs and dances in four stages.

Among them are these songs and dances that condense the common and simple rituals of Tibetan religion, which contain praising the holy mountain (the particular mountain represents a certain lama), killing demons, and hoping for luck. Or we can think that although people today still possess the need for religion, people are unable to do the ritual of hail proof on their own because of its religious gates, and are not willing to ask the ser srung to perform a real religious ritual. Though people today still need a religion, people are not able to do the ritual of hail proof by themselves because of its religious gates, nor are they willing to ask the ser srung to perform a real religious ritual. This reflects from the aspect that Tibetan religion does not fully connect people's life and religion strongly. In other words, this reflects the regional characteristics of the Tibetan religion. That is, the religion leads the Tibetan people, but the religion is not completely in charge. In other words, ordinary Tibetan people know they believe in Buddhism but do not know about it. In a place where religion leads the region. It is almost impossible to imagine that in a region ruled by religion, people would spontaneously use scientific methods to "ward off evil spirits" and thus abolish their religious rituals. With ser srung career heritage lost, it trends to attribute two causes. The first reason is the development of education in Tibet after 1952. When people's channels of knowledge were expanded. It leads to fewer and fewer new Buddhists in Tibet. the Tibetan people no longer be a monk for education, while the content of the study was no longer scriptures, but would study modern science and have the ability to enter Chinese universities. According to the data, from only 60 elementary school students in 1951, the number reached 6360 in 1959 . From 1956 there are now only secondary schools. During the period between the 1959 democratic to the 1966 cultural revolution, the number of students had explosion has greatly harmed the channel of Tibetan religious transmission [11]. Nowadays, if Tibet wants to gain more believers and raise more lama, firstly it needs to let the villagers voluntarily become monks. Tibetan serfdom was abolished after 1959. Therefore, many poor families no longer have to choose to let their extra children become monks and reduce their financial worries. This greatly reduced the possibility of the Tibetan people becoming a monk.

The second reason is the establishment of higher religious education. Also, when the new China was just established, the teaching of scriptures was often a teacher-apprentice system, and religious colleges equipped to confer degrees had not yet been established. Before the establishment of the People's Republic of China, the religious colleges in Tibet were small and only enrolled children under the age of 14. These children were taught to read and write and basic math and arithmetic. In this case, there was not a college with the ability to teach religious literacy. On one hand when modern science helped people solve the problem of hail, nowadays local Tibetan farmers are more inclined to fund the government to use anti-aircraft guns to prevent hail. With the spread of modern education and the fact that the Chinese government banned any religious rituals during the Cultural Revolution, a celebration is held to replace the previous religious rituals. Even though the program at this celebration still has some religious overtones, there is no longer a need for a religious staff to help complete the ritual.

In general, from the beginning, Tibetan Buddhism, to meet the needs of local Tibetan agriculture, learned the hail prevention techniques of the local religion which led to the creation of the specialized profession to meet the needs of the people. the top religious monks but also of the Tibetan nobility. It was apparent long before the founding of the People's Republic of China However, due to the advancement of science and technology, more 
local farmers chose science over religion, even though they were born with a "natural" belief in lama. This means that for most Tibetans, religion is not a necessity or something people can get out of their way, and religion is not that restrictive for people. This is true not only when the British came to Tibet. Although in the Tibetan religion, one's illness is often due to impurity, not only physical but also spiritual impurity. Lama's fecal discharge is considered all sacred in Tibetan Buddhism and can be made into medicine.

\section{CONCLUSION}

This study researched Tibet from ancient times to the beginning of modern Chinese history including how the dominant religions nowadays came to Tibet and how they developed, and how they were influenced by different aspects of the country in the process of development. Based on it, this paper researched the reason for the change of Tibet religion according to two religious rituals that have experienced significant change. In the study of Laze, it is found that the change in rituals were not only of a result religious change and regime change but also of a result of people's demands for a better life. In the study of Hailproof, it is found that the tendency of Tibetan religion was often guided by the upper-class monks or nobles. These people have led the Tibetan religion against China government because of their desire to maintain the present status in a chaotic international political situation, which has resulted in restrictions by the Chinese government. This case study not only explains the factors of the changing needs of the people from the internal perspective, but also the political impact of foreign countries from the external perspective, which will benefit the historical analysis of the changes in the Tibetan special secularism under the influence on the Chinese socialism.

\section{REFERENCES}

[1] Goldstein, M. (1989). A History of Modern Tibet, The demise of the Lamaist State, 1913-1951 (pp. 2324, 27, 33). China Tibetology

[2] Gyatso, Za Thinley. "Narrativity and Historicity: Understanding the Narratives of Sovereignty in the Context of Tibet Question.” The Tibet Journal 42, no. 2 (2017): https://www.jstor.org/stable/90024495.

[3] Zhang Yongpan. (2021, May). The historical necessity and significance of the peaceful liberation of Tibet. China daily. https://cn.chinadaily.com.cn/a/202105/23/WS60a9 87b9a3101e7ce9751108.html

[4] Wang.Xianjun. (2004). Dual system of government in Tibet.
[5] Zhang, A. (2021). Mao Zedong's Strategic Adjustment of Tibetan Religious Policy after the Democratic Reform in Tibet. Science And Atheism, 3, p66. Retrieved 11 September 2021, from.

[6] Grunfeld, A. (1990). The Making of Modern Tibet (pp7, 20, 94-96, 134, 141, 161, 166, 180, 185-187). China Tibetology.

[7] An Analysis of the Cultural Connotation of Tibetan "Laze". (2019). The Sichuan Provincial Committee of the Communist Party of China. Sichuan Party Building.

https://www.zangdiyg.com/index.php?s=/Article/d etail/id/5692.html

[8] Wan, J. (2015). A study of the hail prevention rituals of the Nyingmai 's ser srung". Tibetan Art Studies, 3, p86-88. Retrieved 11 September 2021, CNKI

[9] Sun, L. (2007). A study on Tibetan Folk Religion in the Farming Area of Central Tibet (PhD.d). Sichuan University.

[10] Qing, Y. (2013). The last ser srung "wangjue". China's Tibet, 3, p52-55. Retrieved 11 September 2021, from CNKI.

[11] Ma, R. (1996). The Development of Education in Tibet. Northwestern Journal of Ethnology, 19(2), p160-161. Retrieved 11 September 2021, from CNKI. 